\title{
Transformed Non-Hodgkin Lymphoma
}

National Cancer Institute

\section{Source}

National Cancer Institute. Transformed Non-Hodgkin Lymphoma. NCI Thesaurus. Code C151957.

Histologic transformation of an indolent non-Hodgkin lymphoma to an aggressive nonHodgkin lymphoma. 